\title{
Effect of heat-inactivated Lactobacillus paracasei N1115 on microbiota and gut-brain axis related molecules
}

\author{
Yujie ZHANG ${ }^{1 a}$, Fangfang PU1, 2a, Ruyue CHENG ${ }^{1}$, Jiawen GUO ${ }^{1}$, Xi SHEN ${ }^{1}$, Shijie WANG ${ }^{3}$, Hong ZHU4, \\ Xiao ZHANG ${ }^{1}$, Guo $\mathrm{CHENG}^{5}$, Ming $\mathrm{LI}^{1}$ and Fang $\mathrm{HE}^{1^{*}}$ \\ ${ }^{1}$ Department of Nutrition, Food Safety and Toxicology, West China School of Public Health and West China Forth Hospital, and \\ Healthy Food Evaluation Research Center, Sichuan University, Chengdu, Sichuan, P. R. China \\ ${ }^{2}$ West China Hospital, Sichuan University, Chengdu, Sichuan, P. R. China \\ ${ }^{3}$ College of Bioscience and Bioengineering, Hebei University of Science and Technology, Shijiazhuang, Hebei, P. R. China \\ ${ }^{4}$ Shijiazhuang Junlebao Dairy Co. Ltd., Shijiazhuang, Hebei, P. R. China \\ ${ }^{5}$ Laboratory of Molecular Translational Medicine, Center for Translational Medicine, Key Laboratory of Birth Defects and Related \\ Diseases of Women and Children (Sichuan University), Ministry of Education, Department of Pediatrics, West China Second University \\ Hospital, Sichuan University, Chengdu, Sichuan, P.R. China
}

Received August 31, 2019; Accepted January 31, 2020; Published online in J-STAGE February 19, 2020

\begin{abstract}
This study was conducted to evaluate the possibility of using heated-inactivated lactobacilli to protect neonates from harmful effects of antibiotics. Thirty neonate mice were randomly divided into three groups of ten and treated with either sterilized water, an antibiotics cocktail, or the same antibiotics plus heat-inactivated Lactobacillus paracasei N1115. The administration of antibiotics significantly increased the serum interleukin-6 (IL-6) levels of the tested mice $(p<0.01, p<0.001$, respectively) and decreased their serum corticosterone levels $(p<0.01, p<0.01$, respectively). The colonic crypts were significantly less deep in mice treated with antibiotics and with antibiotics plus N1115 $(\mathbf{p}<0.05)$. Antibiotics caused significantly abnormal expression of brain-derived neurotrophic factor (BDNF), $\gamma$-aminobutyric acid type $A$ receptor $\alpha 1\left(G_{A B A}\right), \gamma$-aminobutyric acid type $B$ receptor1 $\left(G_{A B} A_{b 1}\right)$, and 5-hydroxytryptamine receptor1A $\left(5-\mathrm{HT}_{1 \mathrm{~A}}\right)$ in the hippocampus $(\mathrm{p}<0.05, \mathrm{p}<0.01, \mathrm{p}<0.01$, respectively) and of $\mathrm{GABA}_{\mathrm{A \alpha} 1}$ in the prefrontal cortex $(\mathrm{p}<0.01)$. Heat-inactivated lactobacilli alleviated these abnormal changes. Antibiotics greatly decreased the Shannon index of the fecal microbiota and significantly increased the number of Proteobacteria $(\mathrm{p}<0.001)$, with fewer Bacteroidetes and Firmicutes $(\mathrm{p}<\mathbf{0 . 0 5})$. Antibiotics not only cause microbiota dysbiosis, but also cause abnormal changes in important molecules in the gut-brain axis. All these abnormal changes are alleviated by heat-inactivated $L$. paracase N1115. This indicates that heat-inactivated $L$. paracase $i$ N1115 has a certain improvement effect on changes caused by antibiotics.
\end{abstract}

Key words: heat-inactivated lactobacilli, antibiotics, gut microbiota

\section{INTRODUCTION}

The microbiome is a complex microbial ecosystem of 100 trillion microorganisms residing in the intestinal tract. Microbiota can affect the normal physiological functions of the body and the host's susceptibility to disease through involvement in metabolic processes and interactions with the host [1]. There has been research demonstrating that dysbiosis of the microbiota is associated with some kinds of diseases, such as allergies, obesity, and inflammatory bowel disease (IBD) [2-5].

Recent studies have suggested that the gut microbiota affects not only the intestinal tract but also the organs far from the gut. The brain and the gut are highly integrated organs. Recent research indicated bidirectional communication between the brain and the gut involving both passive and active mechanisms, including neural, immunological, and endocrine pathways and the hypothalamic-pituitary-adrenal (HPA) axis [6-8]. This bidirectional communication is called the microbiome-gut-brain (MGB) axis.

The first 2 years after birth are considered to be a critical period for the gut microbiome development, with the load and diversity of the intestinal flora changing significantly. During this period, the gut microbiome development is complex and influenced by multiple factors including mode of delivery, feeding habits, diet and use of medications, such as antibiotics and probiotics [9-11]. This period is also one of the key periods

ayujie Zhang and Fangfang Pu contributed equally to this work.

*Corresponding author. Fang He (E-mail: hf18602880124@163.com)

(C) 2020 BMFH Press

This is an open-access article distributed under the terms of the Creative Commons Attribution Non-Commercial No Derivatives (by-nc-nd) License

(CC-BY-NC-ND 4.0: https://creativecommons.org/licenses/by-nc-nd/4.0/) 
in brain development [12]. The basic structure of the brain is formed in utero, and the development of brain function begins during this period; if any damage occurs to the brain, it may have extensive impacts on the development of normal functions. Evidence shows that changes in the gut microbiome in early life are related to issues with cognition and memory function [11]. Antibiotics are commonly used as anti-infective drugs during early life and can cause microbiota dysbiosis in the window period of gut microbiota colonization. According to some studies, antibiotic treatment can impair the cognition and memory of mice $[1,13]$. In some studies, the microbiome of mice with depression or anxiety were significantly different from those of healthy mice $[14,15]$. Also, clinical studies show that the gut microbiota of patients with depression, anxiety, or Alzheimer's disease are significantly different from those of healthy people [16-18]. Some clinical trials show that patients with depression have higher levels of Enterobacteriaceae and Alistipes and lower levels of Faecalibacterium than healthy individuals [19]. However, the mechanism by which the gut microbiota might interact with the brain is still not fully understood.

The Food and Agriculture Organization of the United Nations (FAO)/World Health Organization (WHO) defined probiotics as "live microorganisms which when administered in adequate amounts confer a health benefit on the host". In recent years, studies have shown that probiotics can improve an individual's physical health $[20,21]$. Although many studies have investigated the role of probiotics in the promotion of health, probiotics may still have some side effects [22-24]. Moreover, heat-inactivated lactobacilli may be a safer choice. Therefore, research is underway to determine whether heat-inactivated lactobacilli can play the same role as live lactobacilli. Although many studies have investigated the relationship between the gut microbiota and the brain, there are few studies related to heat-inactivated lactobacilli.

In the present study, a mixture of ampicillin, vancomycin, neomycin, bacitracin, imipenem and amphotericin B was orally administered to neonatal mice to induce dysbiosis of the intestinal microbiota of the mice in early life. Heat-inactivated L. paracasei N1115 was also orally administered to the mice treated with antibiotics throughout the course of the study. After the intervention, the mice were evaluated for changes in body weight, organ index, ileal villi depth, colonic crypt depth, and the expression of the cytokines interleukin-6 (IL-6), tumor necrosis factor- $\alpha$ (TNF- $\alpha)$, corticosterone hormones, and some brain signaling molecules. The fecal microbiota of the mice were profiled by next-generation sequencing.

\section{MATERIALS AND METHODS}

\section{Animals}

Twelve pregnant Kunming mice were purchased from the Institute of Laboratory Animal Sciences of the Sichuan Academy of Medical Sciences and Sichuan Provincial People's Hospital (Sichuan, China). The mice were housed in a special pathogenfree facility in individually ventilated plastic cages, and they had free access to water and food. Light conditions (12-hr light/dark cycle), temperature $\left(22 \pm 1{ }^{\circ} \mathrm{C}\right)$ and relative air humidity $(55 \pm 5 \%)$ were tightly controlled. Immediately after birth, pups from the pregnant mice were randomly divided into three groups $(n=10 /$ group): a vehicle group (Veh group), an antibiotics group (Abx group), and a L. paracasei $\mathrm{N} 1115$ group (Abx+N1115 group). All experimental procedures were performed in accordance with the Guidelines for Animal Experiments at West China School of Public Health, Sichuan University (Sichuan, China).

\section{Antibiotic and probiotic treatment}

A mixture of antibiotics consisting of $100 \mathrm{mg} / \mathrm{kg}$ ampicillin, $50 \mathrm{mg} / \mathrm{kg}$ vancomycin, $100 \mathrm{mg} / \mathrm{kg}$ neomycin, $100 \mathrm{mg} / \mathrm{kg}$ bacitracin, $50 \mathrm{mg} / \mathrm{kg}$ imipenem and $1 \mathrm{mg} / \mathrm{kg}$ amphotericin B (Dalian MeilunBiotechnology, Dalian, China) was used to deplete the gut microbiota [13]. L. paracasei N1115 was supplied by Shijiazhuang Junlebao Dairy Co. Ltd. (Shijiazhuang, China). A cell preparation of this bacterium was dissolved in sterile saline and heated at $65^{\circ} \mathrm{C}$ for $2 \mathrm{hr}$. The solution was then centrifuged at $1,000 \times \mathrm{g}$ for $5 \mathrm{~min}$ and washed with phosphate-buffered saline. The heat-inactivated L. paracasei $\mathrm{N} 1115$ re-suspended in distilled water at a concentration of $10^{9} \mathrm{CFU} / \mathrm{mL}$.

The vehicle group was gavaged with distilled water once a day. The Abx group and Abx $+\mathrm{N} 1115$ groups were gavaged with the mixture of antibiotics once a day, while the $\mathrm{Abx}+\mathrm{N} 1115$ group was also gavaged with $10^{9} \mathrm{CFU}$ per mouse of N1115. Intragastric administration was performed using 24-gauge feeding needles attached to a 1-mL syringe (Instech Laboratories, Inc., Plymouth Meeting, PA, USA). The administered dose for each group was $10 \mu \mathrm{L}$ from postnatal days (PND) 0 to 10 and $100 \mu \mathrm{L}$ from PND 10 to 21 [25]. A fixed volume was administered, with the absolute mass configured according to the body weight of the mice.

\section{Enzyme-linked immunosorbent assay (ELISA)}

Mice were sacrificed at PND 21. Blood samples were collected, and serum levels of IL- 6 , TNF- $\alpha$, and corticosterone were measured using ELISA kits (R\&D Systems Inc., Minneapolis, MN, USA) according the manufacturer's instructions.

\section{Histopathology}

The ileum and colon tissues of the mice were collected and fixed in 10\% neutral PBS formalin for $24 \mathrm{hr}$. The tissues were then stained with hematoxylin and eosin. Optical microscopic images were inspected by a pathologist blinded to the experimental design. The length of the ileal villi and depth of the colonic crypts were measured in at last three fields for each mouse.

\section{Realtime polymerase chain reaction (RT-PCR)}

Tissues were collected from the hippocampus and prefrontal cortex of the mice at PND 21 and frozen at $-80^{\circ} \mathrm{C}$. The mRNA expression levels of brain-derived neurotrophic factor (BDNF), $\gamma$-aminobutyric acid type A receptor $\alpha 1\left(\mathrm{GABA}_{\mathrm{A} \alpha 1}\right), \gamma$-aminobutyric acid type $\mathrm{B}$ receptor $1\left(\mathrm{GABA}_{\mathrm{b} 1}\right)$ and 5-hydroxytryptamine receptor $1 \mathrm{~A}\left(5-\mathrm{HT}_{1 \mathrm{~A}}\right)$ were measured using RT-PCR. Total RNA was extracted from the hippocampus and prefrontal cortex using a TRIzol total RNA extraction kit (Chengdu Lanbo Biotechnology Co., Ltd. Chengdu, China). Reverse transcription was performed using an iScript ${ }^{\mathrm{TM}}$ gDNA Clear cDNA Synthesis Kit (Bio-Rad Laboratories, Berkeley, CA, USA).

The reaction system included $5 \mu \mathrm{L}$ of SsoFast EvaGreen supermix, $0.3 \mu \mathrm{L}$ of forward primer and $0.3 \mu \mathrm{L}$ of reverse primer. The PCR cycling conditions were as follows: the reaction conditions were $95^{\circ} \mathrm{C}$ for $30 \mathrm{sec}$, followed by 40 cycles of $95^{\circ} \mathrm{C}$ for $5 \mathrm{sec}$ and $\mathrm{Tm}$ for $5 \mathrm{sec}$; the dissolution curve was read from $65^{\circ} \mathrm{C}$ to $95^{\circ} \mathrm{C}$. 
Table 1. Real-time PCR primers

\begin{tabular}{|c|c|c|c|}
\hline Target & Sequences & Amplicon (bp) & $\operatorname{Tm}\left({ }^{\circ} \mathrm{C}\right)$ \\
\hline$\beta$-actin & Purchased from Sangon Biotech (Shanghai) Co., Ltd. Number: B661302 & 174 & 60 \\
\hline BDNF & $\begin{array}{l}\text { F: } 5^{\prime}-\text { TGG AAC TCG CAA TGC CGA ACT AC }-3^{\prime} \\
\text { R: } 5^{\prime}-\text { TCC TTA TGA ATC GCC AGC CAA TTC TC }-3^{\prime}\end{array}$ & 88 & 58 \\
\hline $\mathrm{GABA}_{\mathrm{A} \alpha 1}$ & $\begin{array}{l}\text { F: 5' - AAA AGT CGG GGT CTC TCT GAC -3' } \\
\text { R: 5'- CAG TCG GTC CAA AAT TCT TGT GA -3' }\end{array}$ & 138 & 58 \\
\hline $\mathrm{GABA}_{\mathrm{b} 1}$ & $\begin{array}{l}\text { F: 5'- ACG TCA CCT CGG AAG GTT G -3' } \\
\text { R: 5'- CAC AGG CAG GAA ATT GAT GGC -3' }\end{array}$ & 107 & 57 \\
\hline $5-\mathrm{HT}_{1 \mathrm{~A}}$ & $\begin{array}{l}\text { F: 5'- TGG GCA ATC ACC GAC CCT AT -3' } \\
\text { R: 5'- TAC CCG TGG TCC TTG CTG AT }-3^{\prime}\end{array}$ & 179 & 55.5 \\
\hline
\end{tabular}

$\beta$-actin (No. B661302, Sangon Biotech Co., Ltd., Shanghai, China) was used as the invariant control, and the levels of mRNA were expressed as fold changes after normalization to $\beta$-actin. Primer sequences are listed in Table 1.

\section{Next-generation sequencing}

Fresh stool samples were collected and frozen at $-80^{\circ} \mathrm{C}$. Total DNA was extracted using TIANamo Stool DNA kits (Tiangen Biotech Co. Ltd., Beijing, China). The reaction for nextgeneration sequencing was conducted as described in our previous work [26]. The data from the next-generation sequencing in this study can be found in NCBI BioProject database under accession number PRJNA546058.
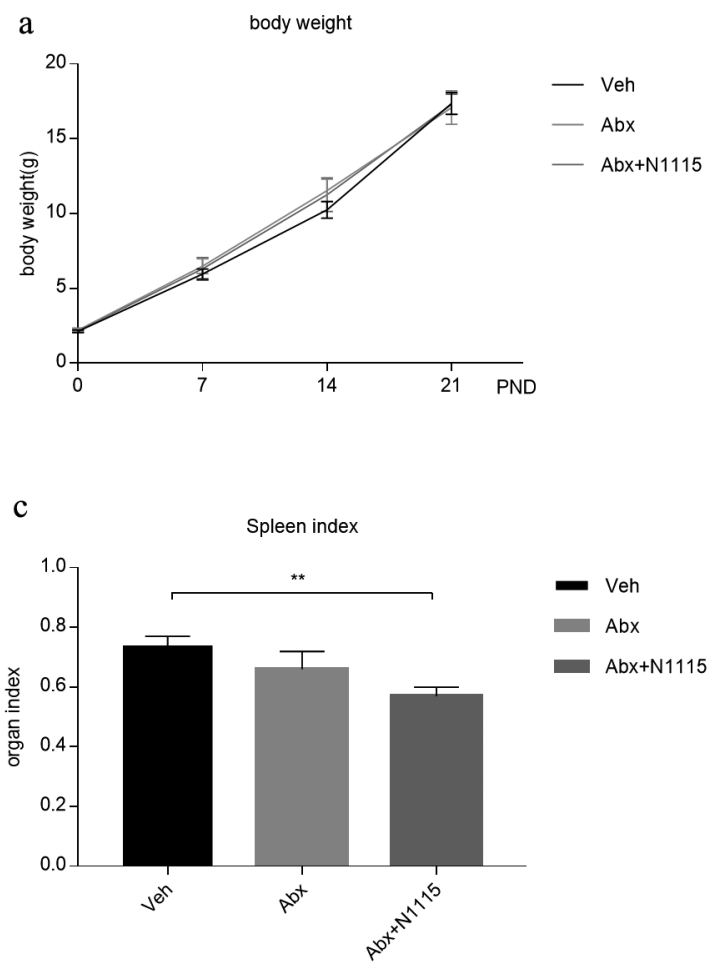

\section{Statistical analysis}

All statistical analyses were performed using IBM SPSS 23.0 (IBM Corp., Armonk, NY, USA). The data were expressed as the mean \pm SME. One-way ANOVA and the Kruskal-Wallis H-test were used for comparisons between groups. A p value $<0.05$ was considered statistically significant.

\section{RESULTS}

\section{Body weight and organ index}

There were no significant differences in body weight between groups (Fig. 1a) or in adrenal index between the test groups (Fig. 1b) at any timepoint. The spleen index of the mice in the
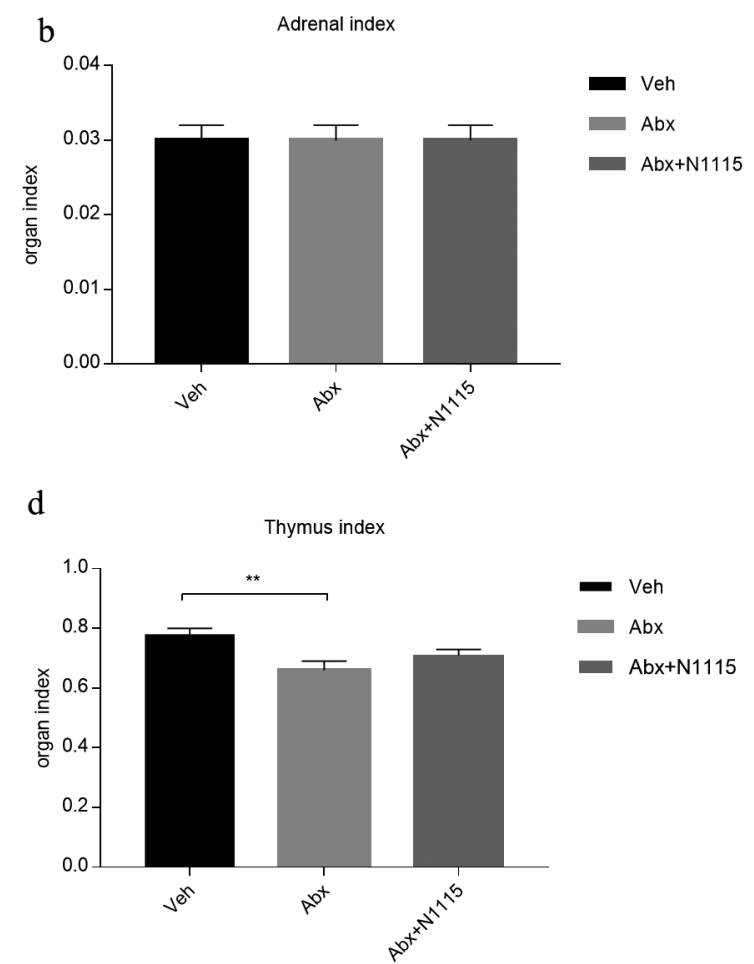

Fig. 1. Body weight and organ index

(a) The weight of mice at postnatal day (PND) $0,7,14$, and 21 . There was no significant difference in body weight between groups at each time point. Adrenal index, spleen index and thymus index of mice were calculated at PND 21. (b) There was no difference in adrenal index between groups. (c) The spleen index of the vehicle group was significantly higher than that of the Abx $+\mathrm{N} 1115$ group $(\mathrm{p}<0.01)$. (d) The thymus index of the vehicle group was significantly higher than that of the Abx group $(\mathrm{p}<0.01) . * * \mathrm{p}<0.01$ for intergroup comparisons. 
$\mathrm{Abx}+\mathrm{N} 1115$ group was significantly decreased compared with that in the vehicle group ( $\mathrm{p}<0.01)$ (Fig. 1c). The thymus index of the Abx group was significantly decreased compared with that in the vehicle group $(p<0.01)$ (Fig. 1d). There were no significant differences between the Abx and $\mathrm{Abx}+\mathrm{N} 1115$ groups for these parameters.

\section{Changes in serum cytokines and corticosterone}

At the end of the experiment, some cytokines and endocrine hormones in serum showed a significant change in the different groups. IL-6 in the Abx group significantly increased compared with those in the vehicle group $(\mathrm{p}<0.01)$ and the $\mathrm{Abx}+\mathrm{N} 1115$ group ( $p<0.001)$, but there was no difference between the vehicle group and the $\mathrm{Abx}+\mathrm{N} 1115$ group (Fig. 2a). The corticosterone level in the Abx group was significantly decreased $(p<0.01)$ compared with that in the vehicle group, while the $\mathrm{Abx}+\mathrm{N} 1115$ group showed no difference compared with the vehicle group (Fig. 2c). There was no difference in TNF- $\alpha$ level in any groups (Fig. 2b).

\section{Changes in intestinal pathology}

Histological analysis of the intestinal morphology showed no significant changes in the ileum villi between the groups (Fig. $3 a)$. The depths of the colon crypts were significantly decreased $(p<0.05)$ in the mice treated with the mixture of antibiotics in the $\mathrm{Abx}$ and $\mathrm{Abx}+\mathrm{N} 1115$ groups (Fig. 3b).

\section{Changes in expression patterns of neural signaling-related molecules in the brain}

Since cognitive performance is impaired in antibiotic-treated mice, we examined the cerebral expression of some neural signaling-related molecules related to learning and memory, which showed different changes in the hippocampus and prefrontal cortex. In the hippocampus, the mRNA expression of BDNF, GABA $A_{A \alpha 1}$, and 5- $\mathrm{HT}_{1 \mathrm{~A}}$ were significantly increased in the Abx group compared with those in the vehicle group $(\mathrm{p}<0.05$, $\mathrm{p}<0.01, \mathrm{p}<0.01$, respectively) and the $A b x+\mathrm{N} 1115$ group $(\mathrm{p}<0.01$, $\mathrm{p}<0.001, \mathrm{p}<0.01$, respectively). The expression of $\mathrm{GABA}_{\mathrm{b} 1}$ in the Abx group was significantly increased compared with that in the $\mathrm{Abx}+\mathrm{N} 1115$ group $(\mathrm{p}<0.05)$. However, there were no significant differences between the vehicle group and the $\mathrm{Abx}+\mathrm{N} 1115$ group (Fig. 4).

The changes in the expression of neural signaling-related molecules in the prefrontal cortex were completely different from those in the hippocampus. The expression levels of $\mathrm{GABA}_{\mathrm{A \alpha} 1}$ in the $A b x$ and the $A b x+N 1115$ groups were significantly decreased $(\mathrm{p}<0.001)$ compared with that in the vehicle group. However, there were no differences in the levels of other neural signalingrelated molecules in the hippocampus among the three groups (Fig. 5).

\section{Structural changes in the gut microbiota}

Treatment with antibiotics and probiotics significantly changed the load and diversity of bacteria in the mice. We analyzed microbial beta-diversity using principal coordinate analysis (PCoA) based on a weighted UniFrac distance to clarify differences in relative bacterial abundance and evolution between the groups. The first principal component (PC1) captured 36.95\% of the variability, indicating a substantial shift in the composition of the microbiota resulting from treatment with antibiotics alone. PC2 captured $25.09 \%$ of the variability, indicating that heat-inactivated $L$. paracasei N1115 restored the gut microbiota disrupted by antibiotics to some extent. The profile of the microbial composition of the $\mathrm{Abx}+\mathrm{N} 1115$ group clustered more closely to the Abx group (Fig. 6), indicating that the use of antibiotics in early life has a major impact on the gut microbiota.
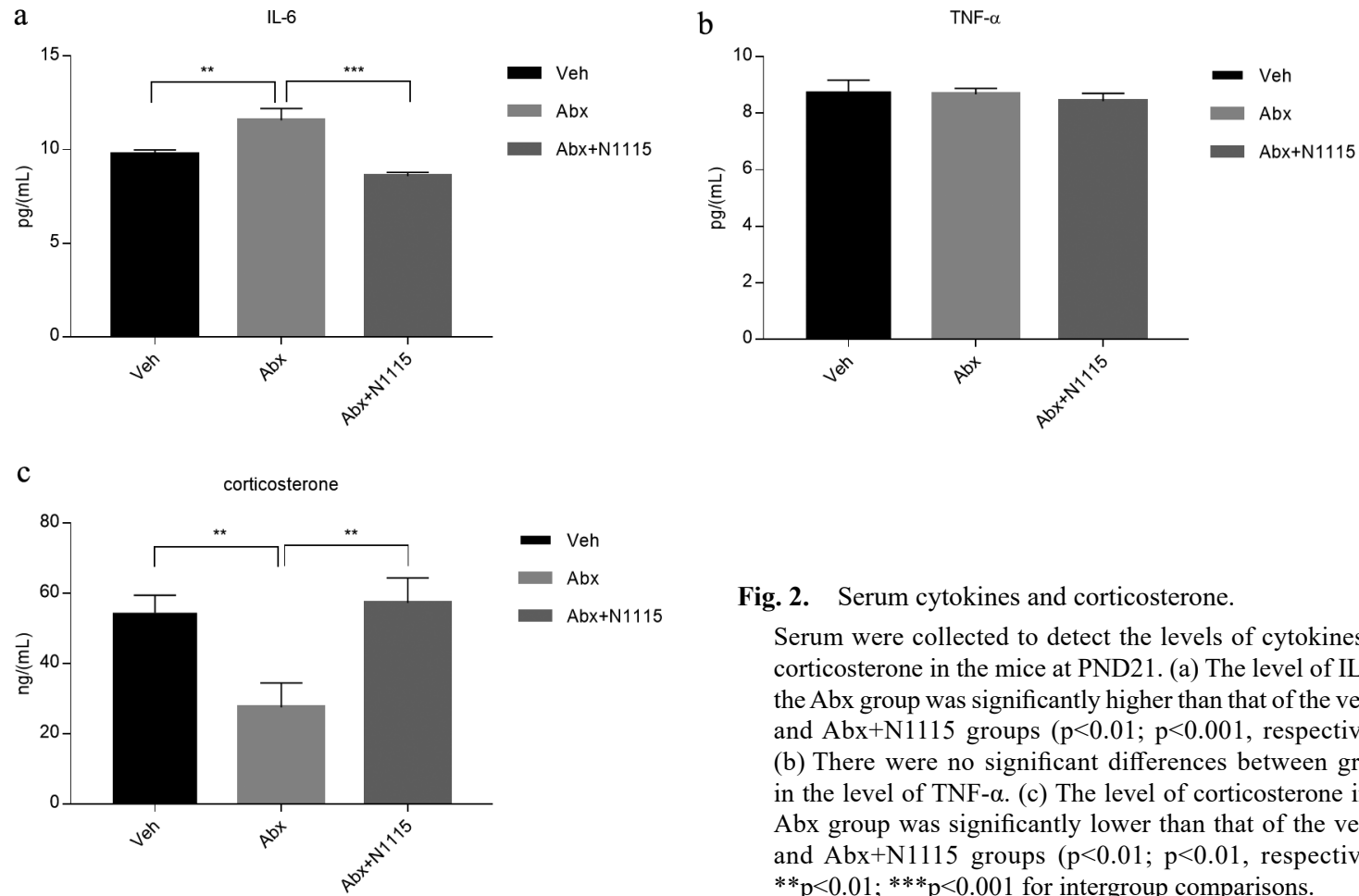

Fig. 2. Serum cytokines and corticosterone.

Serum were collected to detect the levels of cytokines and corticosterone in the mice at PND21. (a) The level of IL-6 in the Abx group was significantly higher than that of the vehicle and $\mathrm{Abx}+\mathrm{N} 1115$ groups $(\mathrm{p}<0.01 ; \mathrm{p}<0.001$, respectively). (b) There were no significant differences between groups in the level of TNF- $\alpha$. (c) The level of corticosterone in the Abx group was significantly lower than that of the vehicle and $\mathrm{Abx}+\mathrm{N} 1115$ groups $(\mathrm{p}<0.01 ; \mathrm{p}<0.01$, respectively). $* * \mathrm{p}<0.01 ; * * * \mathrm{p}<0.001$ for intergroup comparisons. 
a

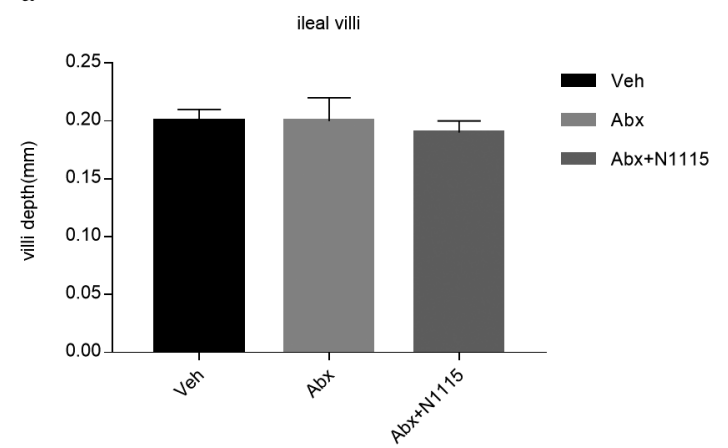

b

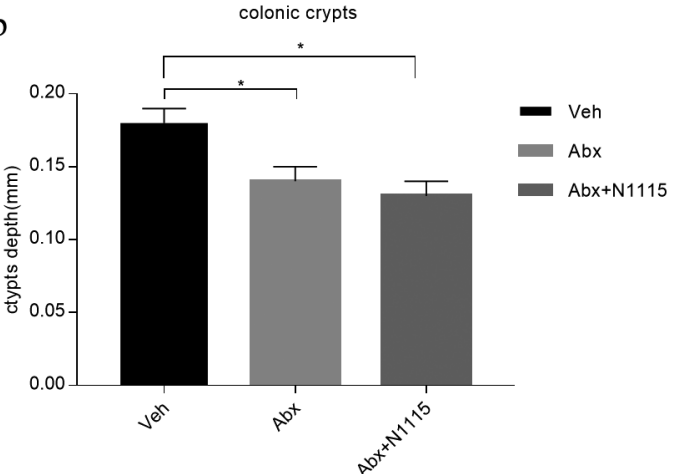

Fig. 3. Results of pathology.

The ileum and colon were collected for pathology. (a) There are no differences in length of ileal villi between groups. (b) The colonic crypts are deeper in the vehicle group than in the Abx group and Abx+N1115 group ( $<<0.05 ; \mathrm{p}<0.05$, respectively). ${ }^{*} \mathrm{p}<0.05$ for intergroup comparisons.

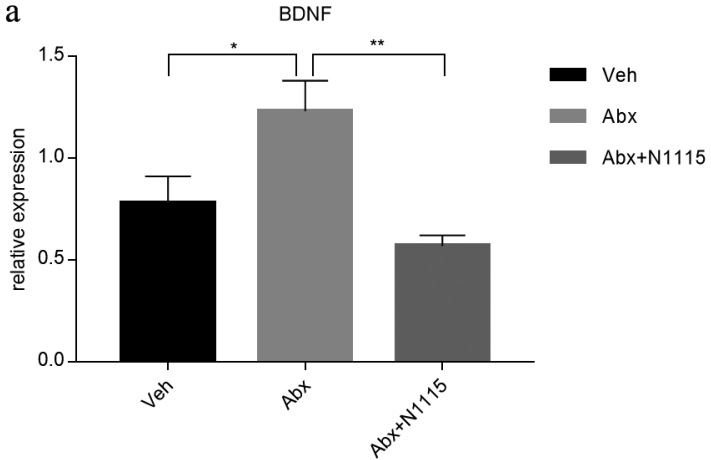

c

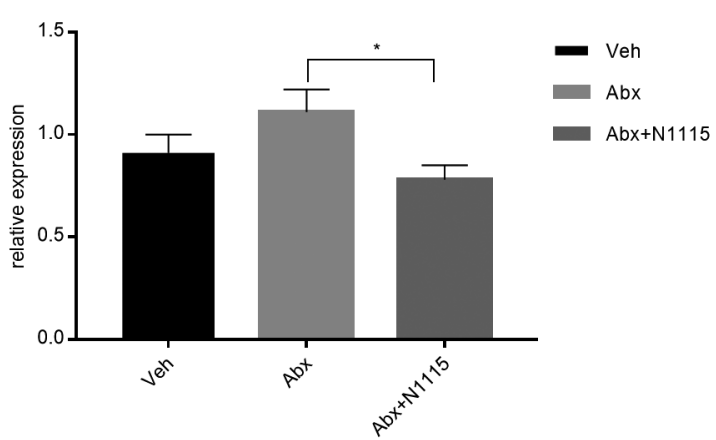

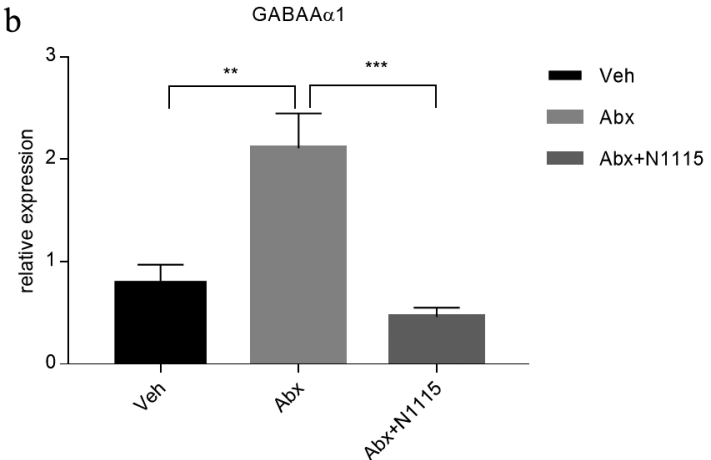

d

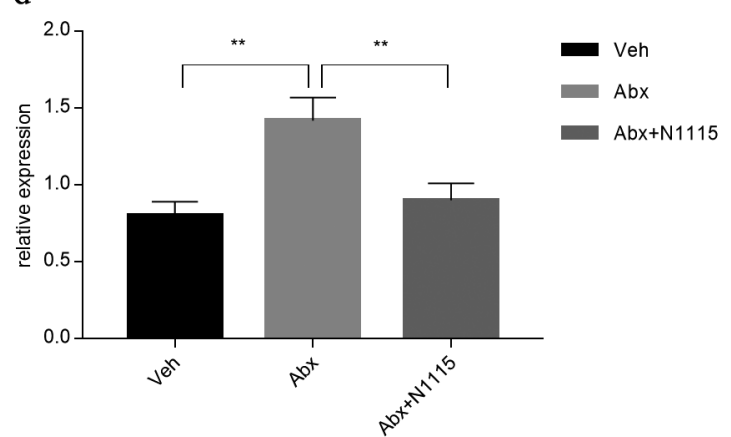

Fig. 4. mRNA expression in the hippocampus.

Hippocampal tissue was collected and examined for the mRNA expression of BDNF, GABA $\mathrm{A \alpha l}_{1}, \mathrm{GABA}_{\mathrm{bl}}$, and 5-HT , $_{\mathrm{A}}$ reporters. (a) The mRNA expression of BDNF in the Abx group is higher than those in the vehicle and $A b x+N 1115$ groups ( $<<0.05 ; p<0.01$, respectively). (b) The mRNA expression of $\mathrm{GABA}_{\mathrm{Aal}}$ in the $\mathrm{Abx}$ group is higher than those in the vehicle and $\mathrm{Abx}+\mathrm{N} 1115$ groups (p $<0.01$; $<<0.001$, respectively). (c) The mRNA expression of $\mathrm{GABA}_{\mathrm{b} 1}$ in the Abx group is higher than that in the Abx+N11115 group (p<0.05). (d) The mRNA expression of 5-HT $1 \mathrm{~A}$ in the Abx group is higher than those in the vehicle and $\mathrm{Abx}+\mathrm{N} 1115$ groups ( $<<0.01 ; \mathrm{p}<0.01$, respectively). ${ }^{*} \mathrm{p}<0.05 ; *{ }^{*} \mathrm{p}<0.01 ; * * \mathrm{p}<0.001$ for intergroup comparisons.

Using probiotics at the same time also had some influence on the composition of the microbiota of the mice.

Compared with the vehicle group, analysis of alpha diversity via the Shannon index revealed a lower diversity in the mice in the $\mathrm{Abx}$ and the $\mathrm{Abx}+\mathrm{N} 1115$ groups $(\mathrm{p}<0.01, \mathrm{p}<0.05$, respectively) (Fig. 7b). However, the Chaol index, which measures the richness of the microbiota did not change after experimental treatment (Fig. 7a).

The composition of the gut microbiota changed significantly, both at the phylum and genus. At the phylum level, Proteobacteria in the Abx and $A b x+N 1115$ groups were significantly increased compared with the vehicle group $(\mathrm{p}<0.001)$, while Bacteroidetes and Firmicutes were significantly decreased $(\mathrm{p}<0.05)$ in the antibiotic-treated groups compared with the vehicle group. The 
a
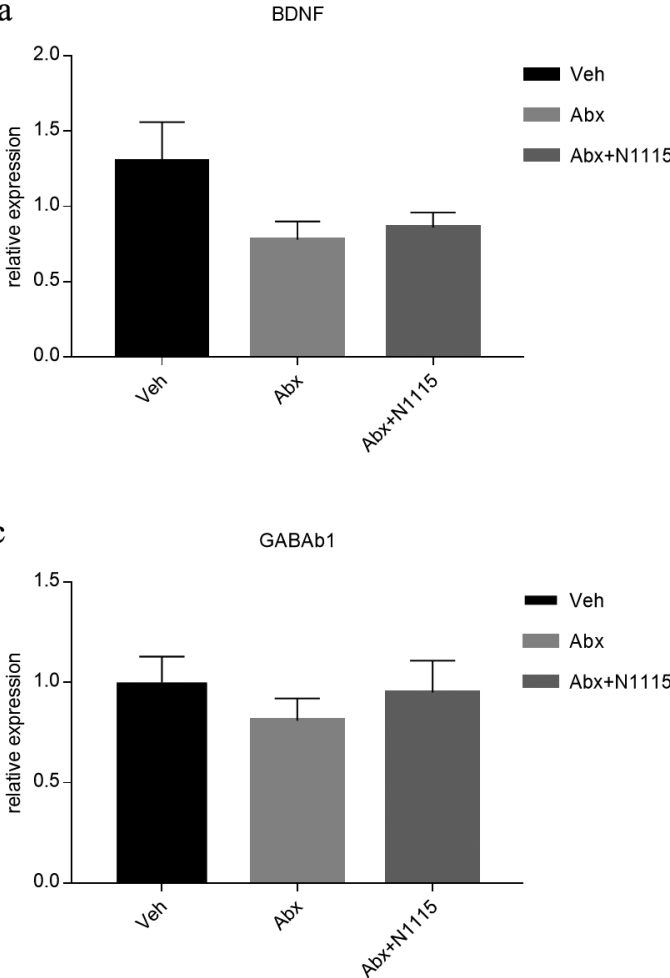

$\mathrm{b}$
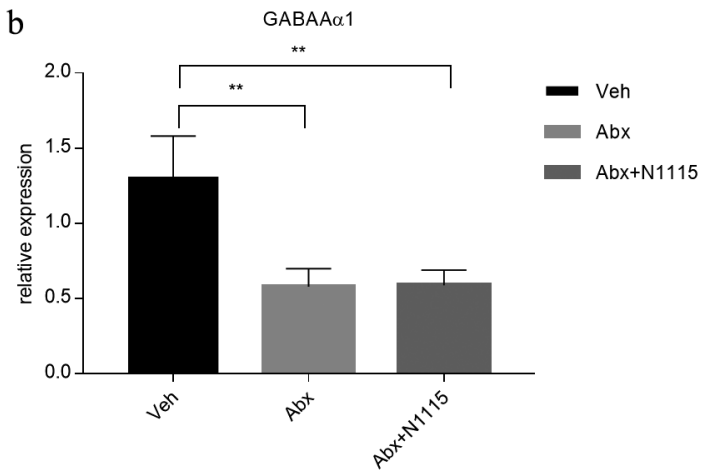

d

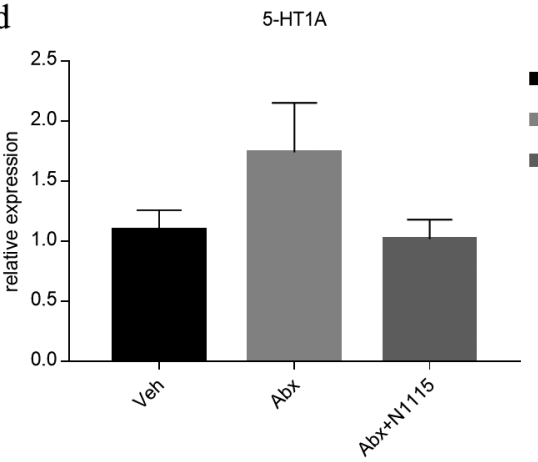

Fig. 5. mRNA expression in the prefrontal cortex.

Prefrontal cortex tissue was collected and examined for the mRNA expression of BDNF, GABA $\mathrm{A \alpha l}_{1}, \mathrm{GABA}_{\mathrm{b} 1}$, and 5-HT $\mathrm{HA}_{1 \mathrm{~A}}$ reporters. (a) There is no difference in the mRNA expression of BDNF between groups. (b) The mRNA expression of $\mathrm{GABA}_{\mathrm{Aal}}$ is higher in the vehicle group than in the $\mathrm{Abx}$ and $\mathrm{Abx}+\mathrm{N} 1115$ groups ( $<0.01 ; \mathrm{p}<0.01$, respectively). (c) There is no difference in the mRNA expression of $\mathrm{GABA}_{\mathrm{b} 1}$ between groups. (d) There is no difference in the mRNA expression of $5-\mathrm{HT}_{1 \mathrm{~A}}$ between groups. ${ }^{* *} \mathrm{p}<0.01$ for intergroup comparisons.

Bacteroidetes to Firmicutes ratio was also significantly decreased in the antibiotic-treated mice (Table 2 and Fig. 8a).

At the genus level, the abundances of Bacteroides and Enterobacter were significantly decreased $(\mathrm{p}<0.01)$ and increased $(\mathrm{p}<0.05)$, respectively, in the mice of the $\mathrm{Abx}+\mathrm{N} 1115$ group compared with the vehicle group, while there were no differences between the Abx and vehicle groups. The numbers of Erwinia, Fusobacterium, Granulicatella, Neisseria, and Streptococcus in the Abx group were significantly increased compared with the vehicle group $(\mathrm{p}<0.05, \mathrm{p}<0.05, \mathrm{p}<0.05, \mathrm{p}<0.01$, respectively). However, there were no differences in the levels of these bacteria between the Abx $+\mathrm{N} 1115$ group and the vehicle group. Klebsiella was significantly increased in the mice treated with antibiotics and became the dominant bacterium $(\mathrm{p}<0.001)$. The levels of Odoribacter, Parabacteroides and Ruminococcus in the antibiotic-treated mice were significantly decreased $(\mathrm{p}<0.05$, $\mathrm{p}<0.001, \mathrm{p}<0.05$, respectively). Oscillospira and Prevotella decreased in the $\mathrm{Abx}+\mathrm{N} 1115$ group compared with the vehicle group ( $<<0.001, \mathrm{p}<0.05$, respectively) (Table 3 and Fig. $8 b$ ).

\section{DISCUSSION}

Lactobacilli and bifidobacteria have been well-documented as providing health benefits and are among the most important microbes used as probiotics. However, accumulating scientific evidence from both clinical and animal studies suggest that the health risks of these microbes should not be ignored, especially when used in infants, the elderly, or immunocompromised patients. The WHO and the Food and Agriculture Organization (FAO) of the United Nations have reported four types of side effects that probiotics may cause: systemic infections, deleterious metabolic activity, excessive immune stimulation in susceptible individuals and gene transfer [27]. Inactivation of probiotics may reduce the damage they can cause to the health of the host and enhance the safety of probiotics. Increasing attention is being focused on exploring the beneficial effects of heat-inactivated Lactobacilli and bifidobacteria [28-30]. Previous studies have demonstrated that even heat-inactivated Lactobacillus gasseri TMC0356 can express an immunomodulatory effect and protect mice against influenza virus infection, as did the living cells of this bacterium [31]. However, the health benefits of probiotics are known to be strain-dependent. L. paracasei N1115 is a new strain originally isolated from traditional fermented products from Inner Mongolia which exhibits high-level resistance to acid and bile stresses [32]. This bacterium has been found to possess the ability to enhance host immunity to protect the elderly from upper respiratory tract infections [33]. Studies have also shown that $L$. paracase $\mathrm{N} 1115$ can alleviate the non-alcoholic fatty liver disease (NAFLD) induced by a high-fat diet and slow down the development of cirrhosis [34, 35]. As a newly isolated strain, there are still few studies on this strain, and these studies have all concentrated on its anti-inflammatory and immune-enhancing effects. We believe that since the strain has a certain ability to regulate immunity, the intestine, as an important part of the 


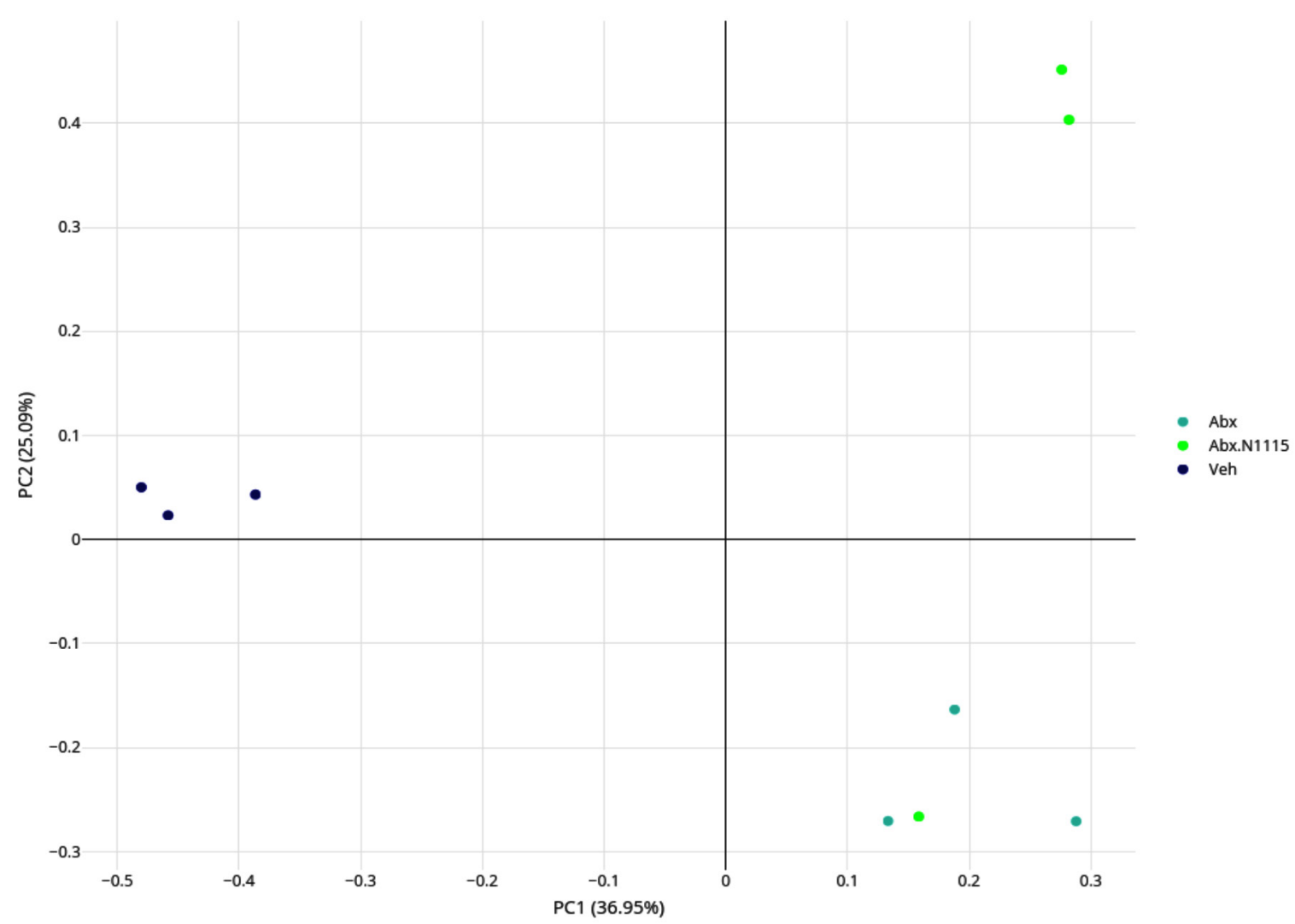

Fig. 6. Analysis of the microbial beta-diversity with principal coordinate analysis (PCoA).

The gut microbiota in each group was analyzed and then indicated with dots of different colors. It can be seen that the antibiotics and the heatedinactive Lactobacillus paracasei N1115 affect the structure of the gut microbiota.

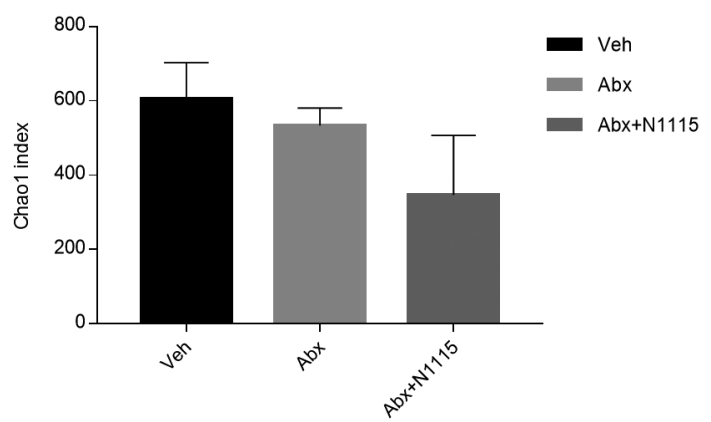

b

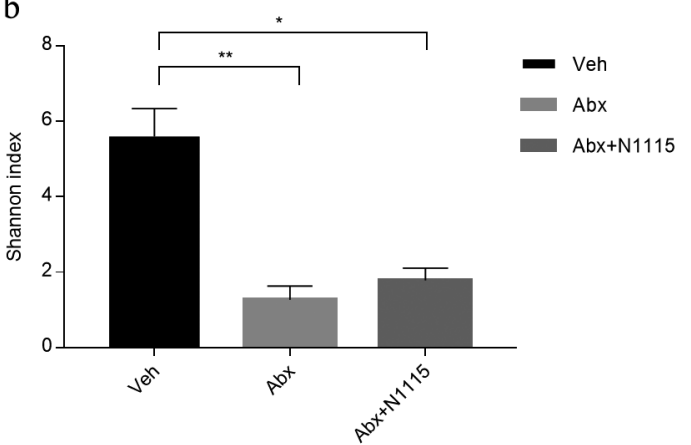

Fig. 7. Diversity and composition of the gut microbiota.

The Chaol index estimates the community richness. The higher the value is, the higher the level of species richness is. The Shannon index estimates the community diversity. The higher the value is, the higher the level of species richness is. Compared with the vehicle group, analysis of alpha diversity via the Shannon index revealed lower diversity in the mice in the Abx and Abx $+\mathrm{N} 1115$ groups $\left({ }^{*} \mathrm{p}<0.01 ; * * \mathrm{p}<0.05\right.$, respectively).

Table 2. Mean relative abundance of different taxa at phylum level

\begin{tabular}{lccc}
\hline \multicolumn{1}{c}{ Phylum } & veh (\%) & Abx (\%) & Abx+N1115 (\%) \\
\hline Proteobacteria & 5.77 & $99.47^{* * *}$ & $99.74^{* * * \#}$ \\
Bacteroidetes & 51.63 & $0.21^{*}$ & $0.05^{*}$ \\
Firmicutes & 39.64 & $0.28^{*}$ & $0.21^{*}$ \\
\hline
\end{tabular}

${ }^{*} \mathrm{p}<0.05, * * * \mathrm{p}<0.001$, comparing with veh.

${ }^{\#} \mathrm{p}<0.05$, comparing with Abx. immune system, will also be affected. The immune system is also an important means of bidirectional communication between the gut and the brain. Therefore, L. paracasei N1115 was tested in this study for its potential to affect the brain through the MGB axis, using a heat-inactivated cell preparation in the presence of antibiotics.

Studies have shown that the use of antibiotics in early life may be related to obesity, but this phenomenon occurs in later 
a
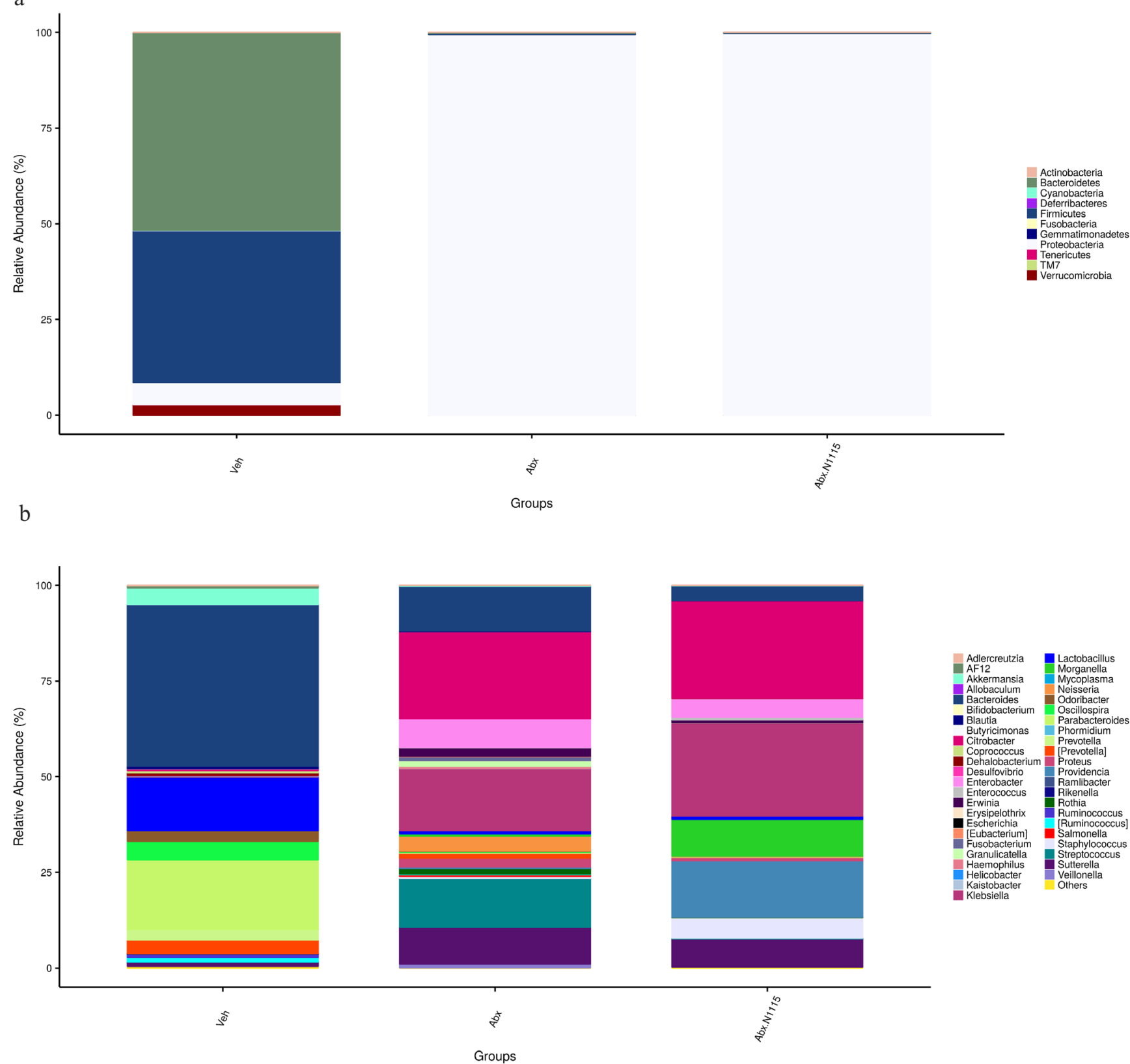

Fig. 8. Flora composition at phylum and genus levels.

The figure shows the phylogenetic classifications of 16S rRNA gene frequencies at the phylum and genus levels. Each bar represents one group. Each color represents a phylum (a) or genus (b). Rare taxa $(<1 \%)$ are classified into others.

years [36, 37]. In the present study, such early life exposure to antibiotics and probiotics also did not cause any changes in body weight or apparent clinical symptoms $[25,26]$. However, the antibiotics used were found to damage the intestine structure of the mice by decreasing the depth of colonic crypts. This may be one of the mechanisms by which antibiotics can regulate or impair the immune function of the host, at least in part.

Abnormal production of serum IL- 6 is considered a hallmark of the inflammation present in various diseases and unhealthy physiological conditions. In the present study, the cocktail of antibiotics significantly increased serum IL-6 in the mice, indicating that the antibiotics enhanced the inflammatory responses of the host animals when used in early life. The heat-inactivated $L$. paracasei $\mathrm{N} 1115$ significantly alleviated the negative influence of the antibiotics on serum IL-6 levels in the mice. On the other hand, the antibiotics used did not influence the serum TNF- $\alpha$ levels of the mice. These results agree with those of previous studies in which antibiotic use also increased serum IL-6 in mice suffering from microbiota dysbiosis induced by antibiotics [38]. Heat-inactivated Lactobacillus rhamnosus GG and Lactobacillus delbrueckii subsp. bulgaricus were found to modulate immune responses by affecting human dendritic cells [39]. Heat-inactivated Lactobacillus sakei probio 65 reduced the level of IL- 6 in serum and alleviated atopic dermatitis in mice 
Table 3. Mean relative abundance of different taxa at genus level

\begin{tabular}{lccc}
\hline \multicolumn{1}{c}{ Genus } & veh (\%) & Abx (\%) & Abx+N1115 (\%) \\
\hline Bacteroides & 42.22 & 11.63 & $3.78^{* *}$ \\
Enterobactr & $<0.1$ & 0.1 & $0.7^{*}$ \\
Erwinia & $<0.1$ & $2.15^{*}$ & 0.63 \\
Fusobacterium & $<0.1$ & $1.07^{*}$ & $<0.1^{\#}$ \\
Granulicatlla & $<0.1$ & $1.49^{*}$ & $0.07^{\#}$ \\
Klebsiella & 0.08 & $16.19^{* * *}$ & $24.4^{* * *}$ \\
Neisseria & $<0.1$ & $3.9^{* *}$ & $0.14^{\# \#}$ \\
Odoribacte & 2.73 & $<0.1^{*}$ & $<0.1^{*}$ \\
Oscillospia & 4.89 & $<0.1$ & $0.07^{* *}$ \\
Parabacteroides & 18.14 & $0.12^{* * *}$ & $0.19^{* * *}$ \\
Prevotella & 2.78 & 1.3 & $<0.1^{*}$ \\
[Ruminococcus] & 0.88 & $<0.1^{*}$ & $<0.1^{*}$ \\
Streptococus & 0.88 & $12.76^{* * *}$ & $0.14^{\#}$ \\
\hline
\end{tabular}

${ }^{*} \mathrm{p}<0.05, * * \mathrm{p}<0.01,{ }^{* * *} \mathrm{p}<0.001$, comparing with veh. $\# \mathrm{p}<0.05$, \#\#p<0.01, comparing with Abx.

[] indicate that the corresponding sequence was included in the Greengene database, but was not included in NCBI.

[29]. Heat-inactivated Lactobacillus plantarum K37 was found to relieve airway hypersensitivity [40]. These studies suggest that specific strains of heat-inactivated lactobacilli might exhibit antiinflammatory effects by down regulating serum IL-6 expression and protecting the host animal from allergic disease. The results of the present study indicated that heat-inactivated L. paracasei N1115 might produce anti-inflammatory effects which prompt the host to develop immunity in early life. Immunity has been welldocumented as one of the critical factors in the development and functioning of the brain. Therefore, heat-inactivated L. paracasei N1115 could affect brain function by influencing the immunity of host animals. We also believe that IL-6 is associated with altered expression of BDNF. The mechanism of this may be regulation of DNA methyltransferase 1 and DNA methyltransferase 3a by IL-6 through phosphoinositide 3-kinase (PI3 K) and protein kinase B (PKB) [41], which can affect the methylation process of BDNF. In this way, BDNF can be regulated [42]. Since IL-6 can pass through the blood-brain barrier, it can mediate the communication between the gut and the brain in a direct and indirect manner.

In this study, heat-inactivated L. paracasei N1115 protected the mice from the negative influence of the antibiotics on serum corticosterone which is an important messenger molecule in the HPA axis. The HPA axis appears to play a key role in bidirectional communication between the gut microbiome and the brain. Therefore, the results of the present study suggest that heatinactivated $L$. paracasei N1115 might interact with the HPA axis to enhance or maintain the homeostasis of corticosterone, thus contributing to the health of the host animal. Any changes that occur during early life may have a profound impact on both the HPA axis and the gut microbiota [43]. HPA axis abnormalities are associated with anxiety, depression, and cognitive dysfunction [44-47]. For example, GF mice were found to have decreased cognitive memory compared with control mice [48, 49]. Antibiotics that induce dysbiosis of the gut microbiota of mice have been shown to produce cognitive defects. The antibiotics can cause some cognitive defects, such as a decline in nonspatial, working memory and non-associative learning [13, 50]. At the same time, some studies have shown that different kinds of antibiotics in clinical treatment may cause many side effects, including confusion, and aphasia [51]. We suggest that these side effects on the brain function is mostly due to changes in the concentration of the inflammatory factors and neurochemicals caused by changes in intestinal flora. Studies have shown that elevated prostaglandin E2 (PEG2) can lead to activation of the HPA axis, which leads to a high level of corticosterone. Prostaglandins may stimulate corticosterone release through an ACTH-independent mechanism. Studies have further shown that the level of corticosterone is also associated with IL-6 [52, 53]. In our study, the corticosterone level decreased after treatment with the antibiotics, while L. paracasei N1115 was shown to induce this abnormal change. This may be because the feedback activation of the HPA axis via the PEG2-mediated pathway occurs earlier and is more influential than IL-6.

The hippocampus plays a very important role in cognition and memory. The prefrontal cortex is the key region for the storage of short-term memory and control of attention [54]. In the hippocampus, the antibiotics significantly increased the expression of BDNF, GABA $\mathrm{A} \alpha 1_{1}$ and $5-\mathrm{HT}_{1 \mathrm{~A}}$ in mice. However, antibiotic treatment downregulated the expression of $\mathrm{GABA}_{\mathrm{A \alpha} 1}$ only in the prefrontal cortex, and heat-inactivated L. paracase $i$ N1115 did not protect the host from the negative effects of the antibiotic on the expression of $\mathrm{GABA}_{\mathrm{A} \alpha 1}$ in the prefrontal cortex, as it did in the hippocampus.

BDNF secreted by both the intestine and the brain plays an important role in promoting neuronal growth and synapse formation [55]. Researchers believe that the changes in BDNF could be related to abnormal cognition, altered memory and the occurrence of some psychiatric disorders, such as Alzheimer's disease and depression $[56,57]$. The results may be related to the cells in the gut secreting BDNF and activating its receptor TrkB. Phosphorylation of the TrkB receptor plays an important role in synaptic formation and cognitive development [58]. Reduction of BDNF and the activation process of TrkB in the intestine may be an important means by which intestinal flora influence brain function. Although most of the above-mentioned studies were based on adolescent or adult mice, the basic structures of the brain and gut are already present at birth. Therefore, we think that this may be one of the ways by which the MGB axis plays an important role. Since there have been few studies on whether age has a specific impact on this pathway, we will perform further research on this aspect in the future.

GABA is an important inhibitory neurotransmitter in the central nervous system. 5-HT is a neurotransmitter, about $90 \%$ of which is synthesized by the gut enterochromaffin cells through a process modulated by the gut microbiome [59]. The $5-\mathrm{HT}_{1 \mathrm{~A}}$ receptor has also been suggested to be involved in memory deficiency [60]. The results of the present study indicated that heat-inactivated L. paracasei N1115 can protect against antibiotic damage to BDNF, GABA $\mathrm{A} \alpha 1_{1}$ and $\mathrm{GABA}_{\mathrm{b} 1}$, and 5-HT in the hippocampus, but not in the prefrontal cortex. There have been several studies in which active probiotics were observed to improve the secretion of BDNF in the brain of mice and the secretion of $\mathrm{GABA}_{\mathrm{A \alpha} 1}$ and $\mathrm{GABA}_{\mathrm{b} 1}[61,62]$. A potential implication of serotonin reuptake in gut dysbiosis-mediated alterations is that it results in a decrease in 5-HT in the circulation, which reduces the compensatory upregulation of $5-\mathrm{HT}_{1 \mathrm{~A}}$ receptors in the brain. Similarly, GABA is an inhibitory neurotransmitter that can be synthesized in the intestine. It can pass the blood-brain barrier to cause hyperpolarization. However, gut microbiota dysbiosis causes a 
change in the concentration of GABA in the circulation, which in turn causes up-regulation or down-regulation of GABA receptors in the brain. This regulatory capacity is regionally dependent, suggesting that the process by which $L$. paracasei $\mathrm{N} 1115$ improve the neurotransmitter pathway by regulating the intestinal flora is also regionally dependent.

Here, the antibiotics used significantly decreased the levels of Bacteroidetes and Firmicutes, causing the gut microbiota of the mice to be dominated by Proteobacteria. It has been previously demonstrated that for optimal health, the dominant members of the normal gut microbiota should be Firmicutes and Bacteroidetes [63]. Proteobacteria is a major phylum of Gram-negative bacteria, which includes a wide variety of pathogens. Therefore, the observed increase in Proteobacteria may be harmful to health. Normal bacteria were decreased, and the proportions of many pathogenic or opportunistic pathogenic bacteria, such as Fusobacterium and Klebsiella, increased in the microbiota of the mice treated with antibiotics. Although some studies indicate that Fusobacterium is a normal resident of the human oropharynx, some research indicates that Fusobacterium is a pathogen [64]. Klebsiella can lead to a variety of diseases, notably pneumonia, urinary tract infections, and diarrhea [65]. Such dynamic changes in the gut microbiota caused by a cocktail of antibiotics could be the cause of the inflammation observed in the treated mice, as assessed by increased levels of IL-6, impairing brain function by reducing serum corticosterone. Here, heat-inactivated $L$. paracasei N1115 showed very limited regulatory effects on the gut microbiota of the mice. This limited regulation may have been because the disorder of the gut microbiota caused by the antibiotics was severe or because of the intervention with the heat-inactivated $L$. paracasei N1115. Therefore, the protective effects of heat-inactivated $L$. paracasei $\mathrm{N} 1115$ might arise mainly from the direct effects of its cellular components, and $L$. paracase $i$ N1115 could have anti-inflammatory effects in the host animal.

In conclusion, the results suggest that the microbiota dysbiosis caused by antibiotics may significantly affect the normal development of brain function in early life through interactions with the immune system, the HPA axis, and the expression of nerve signal-related molecules in the host animal. The heatinactivated $L$. paracasei $\mathrm{N} 1115$ could positively contribute to the development and function of the brain in early life and ameliorate the damage caused by antibiotic, at least in part. However, further studies should be conducted to elucidate the underlying mechanism.

\section{CONFLICT OF INTEREST}

The authors declare that they have no conflicts of interest with respect to this work.

\section{ACKNOWLEDGMENT}

We appreciate the support of the Public Health and Preventive Medicine Provincial Experiment Teaching Center at Sichuan University and Food Safety Monitoring and Risk Assessment Key Laboratory of Sichuan Province. We would like to thank Shijiazhuang Junlebao Dairy Co., Ltd. for providing the probiotic strains for this study.

\section{REFERENCES}

1. Wang T, Hu X, Liang S, Li W, Wu X, Wang L, Jin F. 2015. Lactobacillus fermentum NS9 restores the antibiotic induced physiological and psychological abnormalities in rats. Benef Microbes 6: 707-717. [Medline] [CrossRef]

2. Inoue Y, Shimojo N. 2015. Microbiome/microbiota and allergies. Semin Immunopathol 37: 57-64. [Medline] [CrossRef]

3. Nogacka AM, Salazar N, Arboleya S, Suárez M, Fernández N, Solís G, de Los ReyesGavilán CG, Gueimonde M. 2018. Early microbiota, antibiotics and health. Cell Mol Life Sci 75: 83-91. [Medline] [CrossRef]

4. Zhao L. 2013. The gut microbiota and obesity: from correlation to causality. Nat Rev Microbiol 11: 639-647. [Medline] [CrossRef]

5. Matsuoka K, Kanai T. 2015. The gut microbiota and inflammatory bowel disease. Semin Immunopathol 37: 47-55. [Medline] [CrossRef]

6. Dockray GJ. 2014. Gastrointestinal hormones and the dialogue between gut and brain. J Physiol 592: 2927-2941. [Medline] [CrossRef]

7. Sharon G, Sampson TR, Geschwind DH, Mazmanian SK. 2016. The central nervous system and the gut microbiome. Cell 167: 915-932. [Medline] [CrossRef]

8. Sudo N, Chida Y, Aiba Y, Sonoda J, Oyama N, Yu XN, Kubo C, Koga Y. 2004. Postnatal microbial colonization programs the hypothalamic-pituitary-adrenal system for stress response in mice. J Physiol 558: 263-275. [Medline] [CrossRef]

9. Milani C, Duranti S, Bottacini F, Casey E, Turroni F, Mahony J, Belzer C, Delgado Palacio S, Arboleya Montes S, Mancabelli L, Lugli GA, Rodriguez JM, Bode L, de Vos W, Gueimonde M, Margolles A, van Sinderen D, Ventura M. 2017. The first microbial colonizers of the human gut: composition, activities, and health implications of the infant gut microbiota. Microbiol Mol Biol Rev 81: 81. [Medline] [CrossRef]

10. Yassour M, Vatanen T, Siljander H, Hämäläinen AM, Härkönen T, Ryhänen SJ, Franzosa EA, Vlamakis H, Huttenhower C, Gevers D, Lander ES, Knip M, Xavier RJ, DIABIMMUNE Study Group. 2016. Natural history of the infant gut microbiome and impact of antibiotic treatment on bacterial strain diversity and stability. Sci Transl Med 8: 343ra81. [Medline] [CrossRef]

11. Lim ES, Zhou Y, Zhao G, Bauer IK, Droit L, Ndao IM, Warner BB, Tarr PI, Wang D, Holtz LR. 2015. Early life dynamics of the human gut virome and bacterial microbiome in infants. Nat Med 21: 1228-1234. [Medline] [CrossRef]

12. O'Mahony SM, Clarke G, Dinan TG, Cryan JF. 2017. Early-life adversity and brain development: is the microbiome a missing piece of the puzzle? Neuroscience 342 37-54. [Medline] [CrossRef]

13. Fröhlich EE, Farzi A, Mayerhofer R, Reichmann F, Jačan A, Wagner B, Zinser E, Bordag N, Magnes C, Fröhlich E, Kashofer K, Gorkiewicz G, Holzer P. 2016. Cognitive impairment by antibiotic-induced gut dysbiosis: analysis of gut microbiota-brain communication. Brain Behav Immun 56: 140-155. [Medline] [CrossRef]

14. Guida F, Turco F, Iannotta M, De Gregorio D, Palumbo I, Sarnelli G, Furiano A, Napolitano F, Boccella S, Luongo L, Mazzitelli M, Usiello A, De Filippis F, Iannotti FA, Piscitelli F, Ercolini D, de Novellis V, Di Marzo V, Cuomo R, Maione S. 2018. Antibiotic-induced microbiota perturbation causes gut endocannabinoidome changes, hippocampal neuroglial reorganization and depression in mice. Brain Behav Immun 67: 230-245. [Medline] [CrossRef]

15. Burokas A, Arboleya S, Moloney RD, Peterson VL, Murphy K, Clarke G, Stanton C, Dinan TG, Cryan JF. 2017. Targeting the microbiota-gut-brain axis: prebiotics have anxiolytic and antidepressant-like effects and reverse the impact of chronic stress in mice. Biol Psychiatry 82: 472-487. [Medline] [CrossRef]

16. Naseribafrouei A, Hestad K, Avershina E, Sekelja M, Linløkken A, Wilson R, Rudi K. 2014. Correlation between the human fecal microbiota and depression. Neurogastroenterol Motil 26: 1155-1162. [Medline] [CrossRef]

17. Azpiroz F, Dubray C, Bernalier-Donadille A, Cardot JM, Accarino A, Serra J, Wagner A, Respondek F, Dapoigny M. 2017. Effects of scFOS on the composition of fecal microbiota and anxiety in patients with irritable bowel syndrome: a randomized, double blind, placebo controlled study. Neurogastroenterol Motil 29: 29. [Medline] [CrossRef]

18. Giau VV, Wu SY, Jamerlan A, An SSA, Kim SY, Hulme J. 2018. Gut microbiota and their neuroinflammatory implications in Alzheimer's disease. Nutrients 10: 10 [Medline] [CrossRef]

19. Jiang H, Ling Z, Zhang Y, Mao H, Ma Z, Yin Y, Wang W, Tang W, Tan Z, Shi J, Li L, Ruan B. 2015. Altered fecal microbiota composition in patients with major depressive disorder. Brain Behav Immun 48: 186-194. [Medline] [CrossRef]

20. Steenbergen L, Sellaro R, van Hemert S, Bosch JA, Colzato LS. 2015. A randomized controlled trial to test the effect of multispecies probiotics on cognitive reactivity to sad mood. Brain Behav Immun 48: 258-264. [Medline] [CrossRef]

21. Slykerman RF, Hood F, Wickens K, Thompson JMD, Barthow C, Murphy R, Kang J, Rowden J, Stone P, Crane J, Stanley T, Abels P, Purdie G, Maude R, Mitchell EA, Probiotic in Pregnancy Study Group. 2017. Effect of Lactobacillus rhamnosus HN001 in pregnancy on postpartum symptoms of depression and anxiety: a randomised doubleblind placebo-controlled trial. EBioMedicine 24: 159-165. [Medline] [CrossRef]

22. Boyle RJ, Robins-Browne RM, Tang ML. 2006. Probiotic use in clinical practice: what are the risks? Am J Clin Nutr 83: 1256-1264, quiz 1446-1447. [Medline] [CrossRef]

23. Wassenaar TM, Klein G. 2008. Safety aspects and implications of regulation of probiotic bacteria in food and food supplements. J Food Prot 71: 1734-1741. [Medline] [CrossRef] 
24. Kataria J, Li N, Wynn JL, Neu J. 2009. Probiotic microbes: do they need to be alive to be beneficial? Nutr Rev 67: 546-550. [Medline] [CrossRef]

25. Cheng RY, Li M, Li SS, He M, Yu XH, Shi L, He F. 2017. Vancomycin and ceftriaxone can damage intestinal microbiota and affect the development of the intestinal tract and immune system to different degrees in neonatal mice. Pathog Dis 75: 75. [Medline] [CrossRef]

26. Cheng R, Guo J, Pu F, Wan C, Shi L, Li H, Yang Y, Huang C, Li M, He F. 2019. Loading ceftriaxone, vancomycin, and Bifidobacteria bifidum TMC3115 to neonatal mice could differently and consequently affect intestinal microbiota and immunity in adulthood. Sci Rep 9: 3254. [Medline] [CrossRef]

27. Doron S, Snydman DR. 2015. Risk and safety of probiotics. Clin Infect Dis 60 Suppl 2: S129-S134. [Medline] [CrossRef]

28. Nakamura Y, Terahara M, Iwamoto T, Yamada K, Asano M, Kakuta S, Iwakura Y, Totsuka M. 2012. Upregulation of polymeric immunoglobulin receptor expression by the heat-inactivated potential probiotic Bifidobacterium bifidum OLB6378 in a mouse Intestinal Explant Model. Scand J Immunol 75: 176-183. [Medline] [CrossRef]

29. Kim JY, Park BK, Park HJ, Park YH, Kim BO, Pyo S. 2013. Atopic dermatitismitigating effects of new Lactobacillus strain, Lactobacillus sakei probio 65 isolated from Kimchi. J Appl Microbiol 115: 517-526. [Medline] [CrossRef]

30. Liu YW, Fu TY, Peng WS, Chen YH, Cao YM, Chen CC, Hung WL, Tsai YC. 2015. Evaluation of the potential anti-allergic effects of heat-inactivated Lactobacillus paracasei V0151 in vitro, ex vivo, and in vivo. Benef Microbes 6: 697-705. [Medline] [CrossRef]

31. Shi L, Li M, Miyazawa K, Li Y, Hiramatsu M, Xu J, Gong C, Jing X, He F, Huang C. 2013. Effects of heat-inactivated Lactobacillus gasseri TMC0356 on metabolic characteristics and immunity of rats with the metabolic syndrome. Br J Nutr 109: 263-272. [Medline] [CrossRef]

32. Wang S, Zhu H, He F, Luo Y, Kang Z, Lu C, Feng L, Lu X, Xue Y, Wang H. 2014 Whole genome sequence of the probiotic strain Lactobacillus paracasei $\mathrm{N} 1115$, isolated from traditional Chinese fermented milk. Genome Announc 2: 2. [Medline]

33. Pu F, Guo Y, Li M, Zhu H, Wang S, Shen X, He M, Huang C, He F. 2017. Yogurt supplemented with probiotics can protect the healthy elderly from respiratory infections: a randomized controlled open-label trial. Clin Interv Aging 12: 1223-1231. [Medline] [CrossRef]

34. Yao FF, Zheng PY, Huang H, Bai LM, Ding YR, Mei L, Liu SM. 2017. [Effects of Lactobacillus paracasei $\mathrm{N} 1115$ combined with fructooligosaccharides on non-alcoholic fatty liver disease induced by high-fat diet in mice]. Zhonghua Gan Zang Bing Za Zhi 25: 927-933 (in Chinese). [Medline]

35. Yao F, Jia R, Huang H, Yu Y, Mei L, Bai L, Ding Y, Zheng P. 2019. Effect of Lactobacillus paracasei N1115 and fructooligosaccharides in nonalcoholic fatty liver disease. Arch Med Sci 15: 1336-1344. [Medline] [CrossRef]

36. Murphy R, Stewart AW, Braithwaite I, Beasley R, Hancox RJ, Mitchell EA, ISAAC Phase Three Study Group 2014. Antibiotic treatment during infancy and increased body mass index in boys: an international cross-sectional study. Int J Obes 38: 1115-1119. [Medline] [CrossRef]

37. Azad MB, Bridgman SL, Becker AB, Kozyrskyj AL. 2014. Infant antibiotic exposure and the development of childhood overweight and central adiposity. Int J Obes 38 : 1290-1298. [Medline] [CrossRef]

38. Wan G, Xie M, Yu H, Chen H. 2018. Intestinal dysbacteriosis activates tumor-associated macrophages to promote epithelial-mesenchymal transition of colorectal cancer. Innate Immun 24: 480-489. [Medline] [CrossRef]

39. Giahi L, Aumueller E, Elmadfa I, Haslberger AG. 2012. Regulation of TLR4, p38 MAPkinase, I $\kappa \mathrm{B}$ and miRNAs by inactivated strains of lactobacilli in human dendritic cells. Benef Microbes 3: 91-98. [Medline] [CrossRef]

40. Liu YW, Liao TW, Chen YH, Chiang YC, Tsai YC. 2014. Oral administration of heatinactivated Lactobacillus plantarum $\mathrm{K} 37$ modulated airway hyperresponsiveness in ovalbumin-sensitized BALB/c mice. PLoS One 9: e100105. [Medline] [CrossRef]

41. Hodge DR, Cho E, Copeland TD, Guszczynski T, Yang E, Seth AK, Farrar WL. 2007. IL-6 enhances the nuclear translocation of DNA cytosine-5-methyltransferase 1 (DNMT1) via phosphorylation of the nuclear localization sequence by the AKT kinase. Cancer Genomics Proteomics 4: 387-398. [Medline]

42. Sharma RP, Tun N, Grayson DR. 2008. Depolarization induces downregulation of DNMT1 and DNMT3a in primary cortical cultures. Epigenetics 3: 74-80. [Medline] [CrossRef]

43. Sudo N. 2014. Microbiome, HPA axis and production of endocrine hormones in the gut Adv Exp Med Biol 817: 177-194. [Medline] [CrossRef]

44. Young EA, Abelson JL, Cameron OG. 2004. Effect of comorbid anxiety disorders on the hypothalamic-pituitary-adrenal axis response to a social stressor in major depression. Biol Psychiatry 56: 113-120. [Medline] [CrossRef]
45. Singh A, Petrides JS, Gold PW, Chrousos GP, Deuster PA. 1999. Differential hypothalamic-pituitary-adrenal axis reactivity to psychological and physical stress. J Clin Endocrinol Metab 84: 1944-1948. [Medline]

46. de Winter RF, van Hemert AM, DeRijk RH, Zwinderman KH, Frankhuijzen-Sierevogel AC, Wiegant VM, Goekoop JG. 2003. Anxious-retarded depression: relation with plasma vasopressin and cortisol. Neuropsychopharmacology 28: 140-147. [Medline] [CrossRef]

47. O’Brien JT, Schweitzer I, Ames D, Mastwyk M, Colman P. 1994. The function of the hypothalamic-pituitary-adrenal axis in Alzheimer's disease. Response to insulin hypoglycaemia. Br J Psychiatry 165: 650-657. [Medline] [CrossRef]

48. Gareau MG, Wine E, Rodrigues DM, Cho JH, Whary MT, Philpott DJ, Macqueen G Sherman PM. 2011. Bacterial infection causes stress-induced memory dysfunction in mice. Gut 60: 307-317. [Medline] [CrossRef]

49. Lu J, Synowiec S, Lu L, Yu Y, Bretherick T, Takada S, Yarnykh V, Caplan J, Caplan M, Claud EC, Drobyshevsky A. 2018. Microbiota influence the development of the brain and behaviors in C57BL/6J mice. PLoS One 13: e0201829. [Medline] [CrossRef]

50. Abdurasulova IN, Ekimova IV, Matsulevich AV, Gazizova AR, Klimenko VM, Pastukhov YF. 2017. Impairment of non-associative learning in a rat experimental model of preclinical stage of Parkinson's disease. Dokl Biol Sci 476: 188-190. [Medline] [CrossRef]

51. Warstler A, Bean J. 2016. Antimicrobial-induced cognitive side effects. Ment Health Clin 6: 207-214. [Medline] [CrossRef]

52. Zimomra ZR, Porterfield VM, Camp RM, Johnson JD. 2011. Time-dependent mediators of HPA axis activation following live Escherichia coli. Am J Physiol Regul Integr Comp Physiol 301: R1648-R1657. [Medline] [CrossRef]

53. Dinan TG, Cryan JF. 2012. Regulation of the stress response by the gut microbiota: implications for psychoneuroendocrinology. Psychoneuroendocrinology 37: 13691378. [Medline] [CrossRef]

54. DeYoung CG, Hirsh JB, Shane MS, Papademetris X, Rajeevan N, Gray JR. 2010 Testing predictions from personality neuroscience. Brain structure and the big five. Psychol Sci 21: 820-828. [Medline] [CrossRef]

55. Bistoletti M, Caputi V, Baranzini N, Marchesi N, Filpa V, Marsilio I, Cerantola S, Terova G, Baj A, Grimaldi A, Pascale A, Frigo G, Crema F, Giron MC, Giaroni C. 2019. Antibiotic treatment-induced dysbiosis differently affects BDNF and TrkB expression in the brain and in the gut of juvenile mice. PLoS One 14: e0212856. [Medline] [CrossRef]

56. Hill JM, Bhattacharjee S, Pogue AI, Lukiw WJ. 2014. The gastrointestinal tract microbiome and potential link to Alzheimer's disease. Front Neurol 5: 43. [Medline] [CrossRef]

57. Autry AE, Monteggia LM. 2012. Brain-derived neurotrophic factor and neuropsychiatric disorders. Pharmacol Rev 64: 238-258. [Medline] [CrossRef]

58. Lai KO, Wong AS, Cheung MC, Xu P, Liang Z, Lok KC, Xie H, Palko ME, Yung WH, Tessarollo L, Cheung ZH, Ip NY. 2012. TrkB phosphorylation by Cdk5 is required for activity-dependent structural plasticity and spatial memory. Nat Neurosci 15 : 1506-1515. [Medline] [CrossRef]

59. Yano JM, Yu K, Donaldson GP, Shastri GG, Ann P, Ma L, Nagler CR, Ismagilov RF, Mazmanian SK, Hsiao EY. 2015. Indigenous bacteria from the gut microbiota regulate host serotonin biosynthesis. Cell 161: 264-276. [Medline] [CrossRef]

60. Glikmann-Johnston Y, Saling MM, Reutens DC, Stout JC. 2015. Hippocampal 5-HT1A receptor and spatial learning and memory. Front Pharmacol 6: 289. [Medline] [CrossRef]

61. Mika A, Gaffney M, Roller R, Hills A, Bouchet CA, Hulen KA, Thompson RS, Chichlowski M, Berg BM, Fleshner M. 2018. Feeding the developing brain: juvenile rats fed diet rich in prebiotics and bioactive milk fractions exhibit reduced anxietyrelated behavior and modified gene expression in emotion circuits. Neurosci Lett 677: 103-109. [Medline] [CrossRef]

62. Sun J, Wang F, Hu X, Yang C, Xu H, Yao Y, Liu J. 2018. Clostridium butyricum attenuates chronic unpredictable mild stress-induced depressive-like behavior in mice via the gut-brain axis. J Agric Food Chem 66: 8415-8421. [Medline] [CrossRef]

63. Eckburg PB, Bik EM, Bernstein CN, Purdom E, Dethlefsen L, Sargent M, Gill SR, Nelson KE, Relman DA. 2005. Diversity of the human intestinal microbial flora. Science 308: 1635-1638. [Medline] [CrossRef]

64. Aliyu SH, Marriott RK, Curran MD, Parmar S, Bentley N, Brown NM, Brazier JS, Ludlam H. 2004. Real-time PCR investigation into the importance of Fusobacterium necrophorum as a cause of acute pharyngitis in general practice. J Med Microbiol 53 1029-1035. [Medline] [CrossRef]

65. Podschun R, Ullmann U. 1998. Klebsiella spp. as nosocomial pathogens: epidemiology, taxonomy, typing methods, and pathogenicity factors. Clin Microbiol Rev 11: 589-603. [Medline] [CrossRef] 